\title{
AQUATIC PLANT DIVERSITY OF LAKES AROUND GONDIA CITY, MAHARASHTRA, INDIA
}

\author{
Amol Badole*, Ravindra Zode ${ }^{* *}$, Walay Tagade ${ }^{* *}$, Mahesh Kawale $^{*}$ \\ * Dhote Bandhu Science College, Gondia, India \\ ** Chhotabhai JaverBhai Patel Arts \& Commerce College, Tirora, Gondia, India \\ corresponding author: Mahesh Kawale, e-mail: kawalemahesh@gmail.com
}

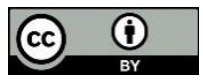

This work is licensed under a

Creative Commons Attribution 4.0

Original scientific paper

International License

Received: May $30^{\text {th }}, 2020$

Accepted: June $29^{\text {th }}, 2020$

HAE-1970

https://doi.org/10.33765/thate.11.2.1

\begin{abstract}
Gondia is one of the centrally located districts of India. It is famous for its lakes and water bodies. These water bodies exhibit enormous diversity of plants according to geographical location, depth of water body, water regime, chemistry of water, soil and sediment characteristics. Very little work has been done so far on the flora of the water bodies of Gondia district. Therefore, a study has carried out to understand the aquatic plants diversity of selected 5 lakes around Gondia city. For this, well-planned surveys were carried out at selected sites frequently. During visits, data like habit, life span, local names, and life forms of all the plant species present in the water body were collected. During the study, 44 species of 37 genera belonging to 26 families have been recorded from selected sites. Most dominant family was Hydrocharitaceae with 4 genera and 4 species, followed by Asteraceae, Poaceae, Convolvulaceae and Potamogetonaceae with 3 species each. Jaccard and Sorenson similarity indexes showed that Lake I and Lake II have maximum similarity and highest diversity as compared to other sites. The present work revealed the database of aquatic plants in water bodies around Gondia, which will help in future work for the conservation, preservation and growth of the local biodiversity.
\end{abstract}

Keywords: aquatic plants, diversity, Gondia, Jaccard \& Sorenson Similarity index, wetlands

\section{INTRODUCTION}

Gondia is a north-eastern border district of Maharashtra state, connected with Chhattisgarh on the eastern side and Madhya Pradesh towards Northern side. Geographically, it is in the centre of India and spread over the area of $5859 \mathrm{~km}^{2}$, out of which $2833 \mathrm{~km}^{2}$ are under forest cover. Gondia is important from the biodiversity point of view as it is a site of two protected areas, i.e. Navegaon Bandh National Park and Nagzira Wildlife Sanctuary. Gondia is also famous for its lakes and ponds, therefore it is considered as the lakes district of Maharashtra. One wellknown Navegaon Bandh lake with wetland is present in the district. Likewise, every village and town of this district has its own lake or water body. Restoration and recharge of water table is possible due to the lakes, thus the lakes 
play an important role in our lives [1]. These water bodies or wetlands exhibit enormous diversity of plants according to geographical location, depth of water body, water regime, chemistry of water, soil and sediment characteristics [2]. Moreover, these water bodies are an integral component of the daily life activities of rural people for their survival, and hence these ecosystems are more vulnerable to eutrophication because of the anthropogenic activities [3]. All these things lead variation in the aquatic plant diversity of water body, which ultimately affects water retaining capacity of wetland day by day.

The researches on aquatic plants have started gaining importance, as they are part of biodiversity. Moreover, they are an important source of food, fodder, herbal medicine and domestic household materials for the people living in its vicinity. There are many aquatic plants which produce corms and rhizomes which are used for an edible purposes in many rural areas. They are also important components of lentic ecosystems. Various researchers have carried out surveys on such aquatic plants in different water bodies across India [4 - 6]. Aquatic plants provide food, oxygen, shelter and breeding place for aquatic animals and maintain the integral balance of the ecosystem [7, 8]. Studies on aquatic plants, especially their ecology, were few in number before 1960s [9]. But, thereafter several studies relating to aquatic and wetland flora have been carried out by many researchers throughout the world, including various parts of India [10 - 15].

Kumar and Chelak [12] studied macrophytic diversity in ponds of Dongargarh city of Chattisgarh and compared their observations with the study conducted earlier and concluded that macrophyte assemblages are changing and are dynamic in different ponds. Two RET (Rare, Endangered and Threatened) species viz. Wolffia arrhiza and Lindernia anagallis of Araceae and Scrophulariaceae family respectively were documented from Gadakharad lake by Dalasingh et al. [16]. Chen et al. [17] also reported that several hydrophyte families, which were not listed on the Red List of China, have been severely threatened in Japan; they also suggested a comprehensive evaluation of the status of hydrophytes in China. It indicates that for conservation measures to be enacted, it is necessary to describe the actual status of aquatic species; however, the distribution data on aquatic macrophyte flora, which is the most basic information necessary for the threatened species, are relatively limited. For example, no floristic data have been obtained for more than 19 major and hundreds of minor lakes found in Gondia district. Hence, present study has been conducted to understand aquatic plant diversity of 5 selected water bodies of Gondia district.

\section{EXPERIMENTAL}

\section{Study Site}

Gondia district is situated at $80.1961^{\circ} \mathrm{E}$ longitude and $21.4549^{\circ} \mathrm{N}$ latitude. For the study of aquatic plants, 5 sites were selected around Gondia city and a survey was carried out during the months of July 2019 to February 2020. The selected lakes were Katangi kala (henceforth referred to as Lake I), Lohara (henceforth referred to as Lake II), Fulchur (henceforth referred to as Lake III), Pangdi (henceforth referred to as Lake IV), and Karanja (henceforth referred to as Lake V) (Table 1, Figure 1).

Table 1. Morphometric data of selected sites [18]

\begin{tabular}{|c|c|c|c|c|}
\hline Lakes & $\begin{array}{c}\text { Surface } \\
\text { area, } \mathrm{m}^{2}\end{array}$ & $\begin{array}{c}\text { Max. } \\
\text { depth, } \\
\mathrm{m}\end{array}$ & $\begin{array}{c}\text { Mean } \\
\text { depth, } \mathrm{m}\end{array}$ & $\begin{array}{c}\text { Retention } \\
\text { time }\end{array}$ \\
\hline I & 22500 & 3.50 & 1.75 & 8 months \\
\hline II & 89031 & 3.05 & 2.00 & 8 months \\
\hline III & 50000 & 4.10 & 2.00 & 9 months \\
\hline IV & 729300 & 12.50 & 5.50 & 12 months \\
\hline V & 25100 & 5.49 & 3.20 & 12 months \\
\hline
\end{tabular}




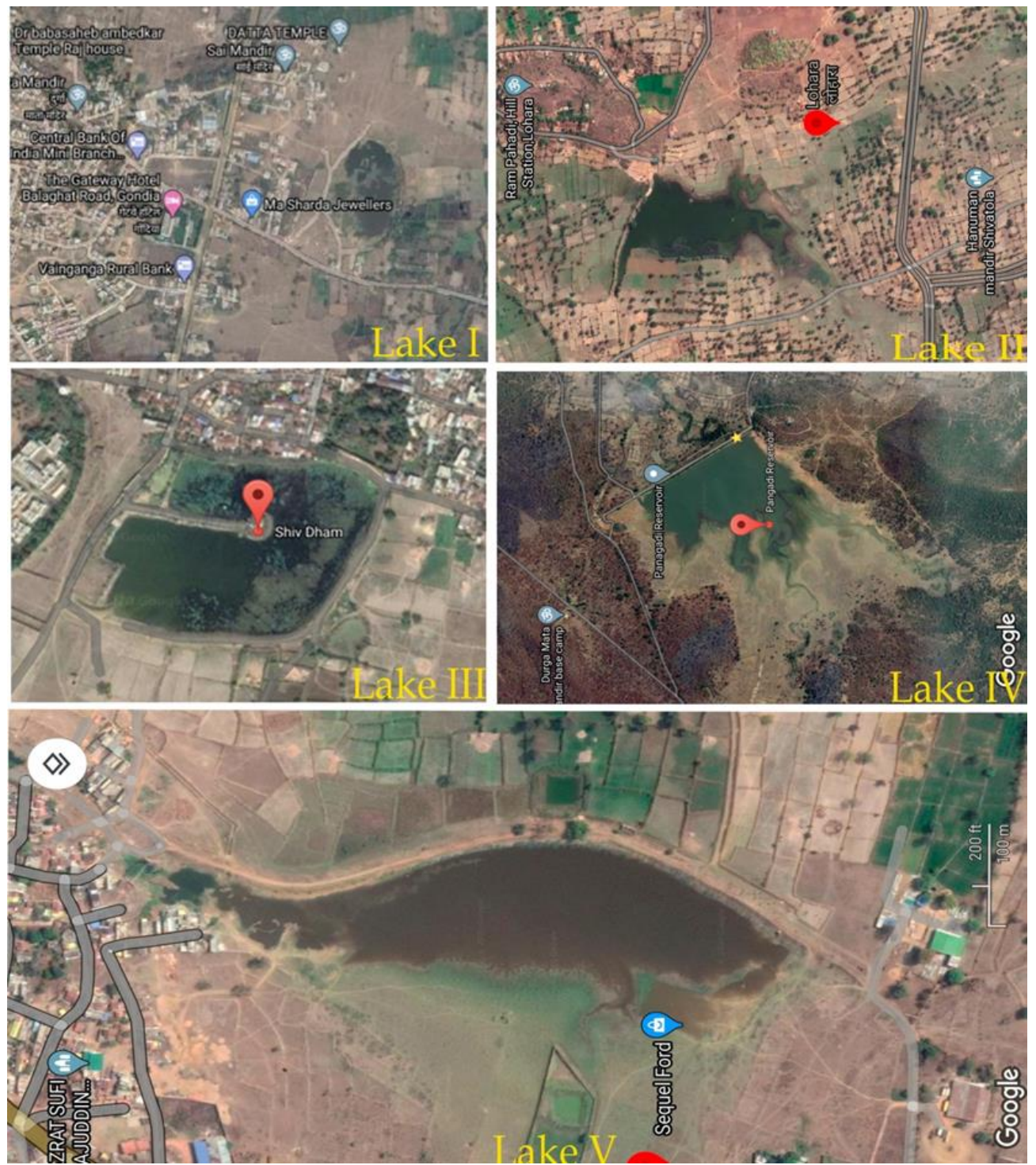

Figure 1. Satellite images of selected sites: Lake I [19], Lake II [20], Lake III [21], Lake IV [22] and Lake V [23]

\section{Collection of aquatic plants}

All these lakes were visited regularly during the period of survey and aquatic plants were collected and photographed. Collected plants were brought to the laboratory and identified there by using standard floras like Flora of Maharashtra state, Flora of Nagpur District, Flora of Kolhapur and Flora of Madhya Pradesh [24 - 27].

\section{Analysis of collected data}

From the collected species, data like habit, life span, local names gathered and tabulated for analysis. Collected plants (uprooted or detached twig) pressed under newspaper for the herbarium preparation. These collected plants are classified on the basis of their habitat, family, morphological characters. They were also analysed according to the habit of life forms, i.e. whether they are free floating, emergent, submerged or rooted floating, etc. From the data of presence or absence of plants at different sites, Jaccard's similarity index (JSI) [28] was applied and analysed:

$$
S_{J}=a /(a+b+c)
$$


where is: $\mathrm{S}_{\mathrm{J}}$ - Jaccard's similarity coefficient, a - number of species in both sites, $b$ - number of species absent in $\mathrm{A}$ but present in $\mathrm{B}, \mathrm{c}$ number of species present in $\mathrm{A}$ but absent in B.

The above aquatic plant data was also analysed by Sorensen's similarity index (SSI) [29]. This measure is very much similar to Jaccard's measure:

$$
\mathrm{S}_{\mathrm{S}}=2 \mathrm{a} /(2 \mathrm{a}+\mathrm{b}+\mathrm{c})
$$

where is: $\mathrm{S}_{\mathrm{S}}$ - Sorensen's similarity coefficient, $\mathrm{a}$ - number of species in both sites, $\mathrm{b}$ - number of species absent in A but present in B, c number of species present in $\mathrm{A}$ but absent in B.

\section{RESULTS AND DISCUSSION}

A total 44 species of aquatic plants representing 37 genera belonging to 26 families have been recorded from the selected 5 sites. Out of these, 41 species of 34 genera covering 24 families were Angiosperm, 2 species of 2 genera representing 1 family were Algae and 1 species of 1 genera representing 1 family was Pteridophyte. Amongst the Angiosperm, 24 dicot species belong to 19 genera and 14 families and 17 monocot species belong to 15 genera and 10 families were found (Figure 2).

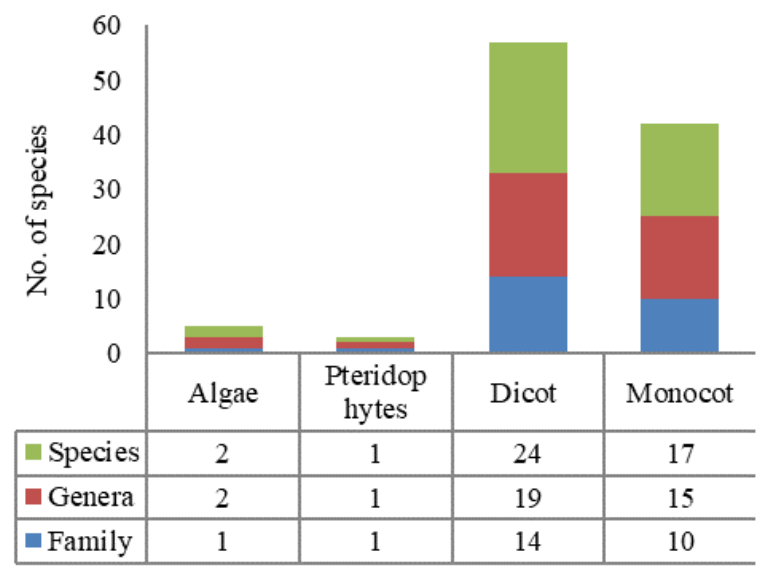

Figure 2. Distribution on the basis of plant types
During the study, 32 genera were represented with single species, 4 genera by 2 species each and 1 genera by 3 species (Table 2). Hydrocharitaceae were found to be the most observed family with 4 genera and 4 species, followed by Asteraceae, Poaceae, Convolvulaceae and Potamogetonaceae with 3 species each. Families like Amaranthaceae, Characeae, Lythraceae, Menyanthaceae, Onagraceae, and Scrophulariaceae were represented by 2 species each and all the remaining families were represented by 1 species only (Tables 2 and 3 and Figure 3 ). Lakshmanan and Gathi [4] also reported the dominance of Hydrocharitaceae, Poaceae along with Convolvulaceae family in selected wetlands of Tamilnadu.

Table 2. Categorization of families and genera according to number of species

\begin{tabular}{|c|c|c|c|c|c|}
\hline $\begin{array}{c}\text { Sr. } \\
\text { No. }\end{array}$ & Categories & $\begin{array}{c}\text { No. of } \\
\text { families }\end{array}$ & $\begin{array}{c}\text { Sr. } \\
\text { No. }\end{array}$ & Categories & $\begin{array}{c}\text { No. of } \\
\text { genera }\end{array}$ \\
\hline 1 & $\begin{array}{c}\text { Families } \\
\text { with 1 } \\
\text { species }\end{array}$ & 15 & 1 & $\begin{array}{c}\text { Genera } \\
\text { with 1 } \\
\text { species }\end{array}$ & 32 \\
\hline 2 & $\begin{array}{c}\text { Families } \\
\text { with 2 } \\
\text { species }\end{array}$ & 6 & 2 & $\begin{array}{c}\text { Genera } \\
\text { with 2 } \\
\text { species }\end{array}$ & 4 \\
\hline 3 & $\begin{array}{c}\text { Families } \\
\text { with 3 } \\
\text { species }\end{array}$ & 4 & 3 & $\begin{array}{c}\text { Genera } \\
\text { with 3 } \\
\text { species }\end{array}$ & 1 \\
\hline 4 & $\begin{array}{c}\text { Families } \\
\text { with 4 } \\
\text { species }\end{array}$ & 1 & 4 & $\begin{array}{c}\text { Genera } \\
\text { with 4 } \\
\text { species }\end{array}$ & 0 \\
\hline \multicolumn{4}{|c|}{}
\end{tabular}

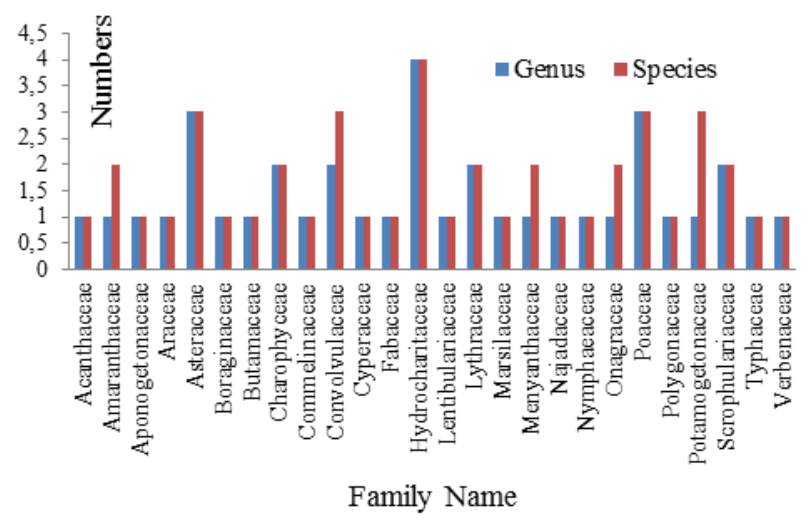

Figure 3. Family-wise distribution of genus and species 
Table 3. Details of plants observed in the study

\begin{tabular}{|c|c|c|c|c|c|}
\hline $\begin{array}{l}\text { Sr. } \\
\text { No. }\end{array}$ & Plant name & Family & $\begin{array}{c}\text { Vernacular } \\
\text { name }\end{array}$ & Habit & Life span \\
\hline 1 & Aeschynomene aspera & Fabaceae & Laugauni & Emergent & Perennial \\
\hline 2 & Alternanthera pubescence & Amaranthaceae & - & Emergent & Perennial \\
\hline 3 & Alternanthera sessilis & Amaranthaceae & Kanchari & Emergent & Perennial \\
\hline 4 & Amania bacifera & Lythraceae & Aginbuti & Emergent & Annual \\
\hline 5 & Aponogeton natans & Aponogetonaceae & - & Rooted floating & Perennial \\
\hline 6 & Blyxa aubertii & Hydrocharitaceae & - & Rooted floating & Annual \\
\hline 7 & Butomopsis lanceolata & Butamaceae & - & Rooted floating & Annual \\
\hline 8 & Chara deliculata & Characeae & - & Submerged & Annual \\
\hline 9 & Commelina benghalensis & Commelinaceae & Kena & Emergent & Perennial \\
\hline 10 & Eclipta prostrata & Asteraceae & Bhringranj & Emergent & Annual \\
\hline 11 & Elytrophorus spicatus & Poaceae & Janglirala & Emergent & Annual \\
\hline 12 & Evolvulus nummularius & Convolvulaceae & Nimulvel & Emergent & Perennial \\
\hline 13 & Gnaphalium polycaulon & Asteraceae & - & Emergent & Annual \\
\hline 14 & Grangea maderaspatana & Asteraceae & Godri & Emergent & Annual \\
\hline 15 & Heliotropium indicum & Boraginaceae & Burundi & Emergent & Annual \\
\hline 16 & Hydrila verticillata & Hydrocharitaceae & Seval & Submerged & Perennial \\
\hline 17 & Hygrophila auriculata & Acanthaceae & Talimkhana & Emergent & Annual \\
\hline 18 & Ipomoea aquatica & Convolvulaceae & Panivel bhaji & Rooted floating & Perennial \\
\hline 19 & Ipomoea fistula & Convolvulaceae & Besharam & Emergent & Perennial \\
\hline 20 & Limnophila heterophylla & Scrophulariaceae & Ambuli & Emergent & Annual \\
\hline 21 & Ludvigia ascendence & Onagraceae & Kavkula & Rooted floating & Annual \\
\hline 22 & Ludvigia parviflora & Onagraceae & Pan-lavang & Emergent & Annual \\
\hline 23 & Marsilea quadrifolia & Marsilaceae & Caupatia & Rooted floating & Annual \\
\hline 24 & Najas graminea & Najadaceae & - & Submerged & Annual \\
\hline 25 & Nitella gracillis & Characeae & - & Submerged & Annual \\
\hline 26 & Nymphaea nauchali & Nymphaeaceae & Kamal & Rooted floating & Perennial \\
\hline 27 & Nymphea sp. & Nymphaeaceae & - & Free floating & Annual \\
\hline 28 & Nymphoides hydrophylla & Menyanthaceae & Kamali & Free floating & Annual \\
\hline 29 & Nymphoides indicum & Menyanthaceae & Kumudini & Free floating & Perennial \\
\hline 30 & Oryza sp. & Poaceae & Devtandul & Rooted floating & Annual \\
\hline 31 & Ottelia alismoidis & Hydrocharitaceae & - & Submerged & Annual \\
\hline 32 & Phyla nodiflora & Verbenaceae & Jalpimpri & Emergent & Perennial \\
\hline 33 & Pistia strtiotes & Araceae & PanKumbhi & Free floating & Perennial \\
\hline 34 & Polygonum glybrum & Polygonaceae & Gulabi Godhri & Emergent & Annual \\
\hline 35 & Potamogeton crispus & Potamogetonaceae & Sawal & Submerged & Perennial \\
\hline 36 & Potamogeton natans & Potamogetonaceae & - & Rooted floating & Annual \\
\hline 37 & Potamogeton sp. & Potamogetonaceae & - & Rooted floating & Annual \\
\hline 38 & Rotala fimbriata & Lythraceae & - & Emergent & Annual \\
\hline 39 & Sacciolepsis intrupta & Poaceae & - & Rooted floating & Perennial \\
\hline 40 & Schenoplectus sp. & Cyperaceae & $\mathrm{Gad}$ & Emergent & Annual \\
\hline 41 & Striga densifera & Scrophulariaceae & Agya & Emergent & Annual \\
\hline 42 & Typha angustifolia & Typhaceae & Pan-kanis & Emergent & Perennial \\
\hline 43 & Utricularia reticulata & Lentibulariaceae & Nili Papni & Submerged & Annual \\
\hline 44 & Vallisneria spiralis & Hydrocharitaceae & Seval & Submerged & Perennial \\
\hline
\end{tabular}

The plant diversity is a strong bio-indicator for lake ecosystems differed in types and response [30]. The aquatic plant species diversity of 5 lakes was found to be healthy as Pistia strtiotes was the only invasive alien plant found there. Lake II had the highest number of species (35 spp.), followed by Lake III (28 spp.), Lake I (22 spp.), Lake V (20 spp.) and Lake IV (15 spp.). A total of 35 aquatic plant species ( $80 \%$ of the total recorded species) were confined only to Lake II, out of the 5 lakes. On the other hand, Lake IV and V had the lowest number of confined species (Figure 4).

It has been observed by Kohtaroh et al. [10] that floristic diversity of any pond depends upon some factors like size, depth or shallowness of the water body, sediment deposition, seed sources, as well as the recent history of the water body regarding any type of excavation. Boyra and Patralekh [31] also 
reported that aquatic plants occur mainly in the shallow regions of lakes, ponds or any water body. In the present study, a clear pattern is observed, in which the plant species coverage increased when the depth of lake decreased. It indicates that aquatic plant diversity of Lake IV (15 plant species) is negatively correlated with the lake surface area and depth, whereas Lake II (35 plant species) showed positive correlation with the lake surface area and depth as compared to rest of the lakes (Tables 1 and 4 and Figure 4). Different areas of a lake can have water depths variation because of the diverse topography of the lake bottom. Depth plays a very important role in the growth of aquatic plants, as the factors like water transparency, water temperature, availability of light, and light regime have effect on it [32]. Changes in all of these factors can affect the growth and distribution of submerged plants and structure of communities [33]. There are many reports which showed effects of water depth on the growth of the submerged species Myriophyllum spicatum [34, 35], Potamogeton pectinatus [36], Potamogeton maackianus and Potamogeton malaianus [37, 38] and on the community composition of the submerged macrophytes [39].

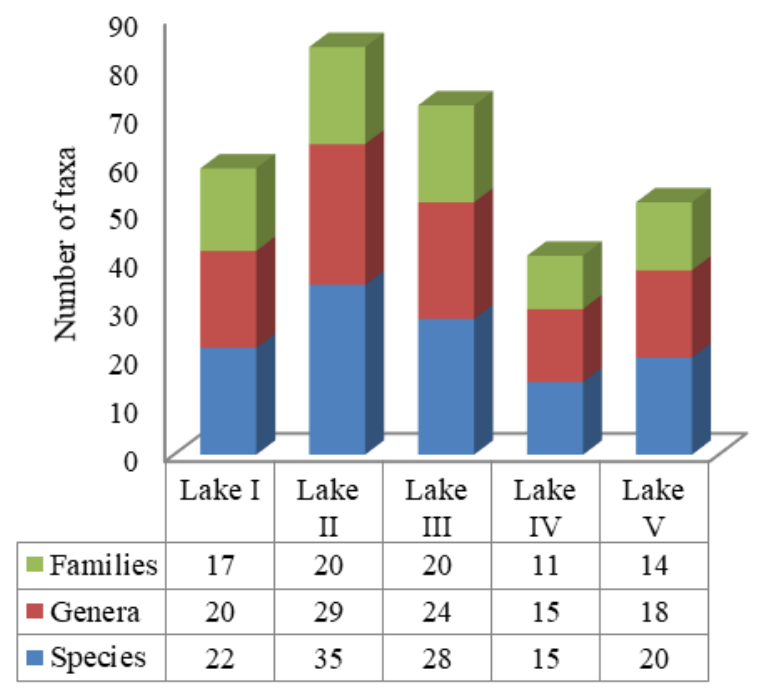

Figure 4. Sitewise distribution of taxa

Lake I, II and III are seasonal i.e. they carry water for 8 - 9 months of a year, while Lake $\mathrm{IV}$ and $\mathrm{V}$ store water throughout year (Table 1). Hence, grazing by domestic cows and buffaloes are observed around Lake I, II and
III during certain periods of the year which may increase the plant diversity. This result is in accordance with hypothesis concerning the role of disturbances and productivity in biodiversity [40, 41]. In addition to these, some anthropogenic activities, like fishing, could also be the reason behind variation in aquatic plant diversity in selected lakes. Fishing is carried out in Lake IV and V in most of the part of year which is not found in Lake I, II and III.

Plant species like Ipomoea fistula, Nitella gracillis, Evolvulus nummularius, Hygrophila auriculata, Grangea maderaspatana, Ludvigia parviflora and Alternanthera sessilis were observed in all 5 sites. However, species like Nymphoides indicum, Potamogeton crispus, Blyxa aubertii, Butomopsis lanceolate, Striga densifera, Limnophila heterophylla and Polygonum glybrum were only found at Lake II. Similarly, plants like Pistia strtiotes, Commelina benghalensis and Najas graminea were found absent in all other lakes except Lake III. Elytrophorus spicatus belonging to Poaceae family was found only in Lake IV, even though this site has least plant diversity as compared to other lakes (Table 4).

Significant phyto-social association had been recorded among the different aquatic plants of studied lakes, like Vallisneria spiralis was always found in association with Chara deliculata. Wherever Ludvigia parviflora was found, Alternanthera sessilis was also observed nearby. Similarly, Nymphoides hydrophylla and Potamogeton natans, Ludvigia ascendence and Ipomoea aquatic, Nymphaea nauchali and Nymphoides hydrophylla, Otelia alismoidis and Potamogeton natans, Hygrophila auriculata and Alternanthera pubescence were also found together in some lakes (Table 4, Figure 5). Zervas et al. [42] studied phytosociological aspect of aquatic vegetation at Greece in large scale and observed many plant associations with Phyla nodiflora, Phragmites australis, Lemna minor etc. 
Table 4. Sitewise distribution of aquatic plants

\begin{tabular}{|c|c|c|c|c|c|c|c|c|}
\hline $\begin{array}{l}\text { Sr. } \\
\text { No. }\end{array}$ & Plant name & $\begin{array}{c}\text { Lake } \\
\text { I }\end{array}$ & $\begin{array}{l}\text { Lake } \\
\text { II }\end{array}$ & $\begin{array}{c}\text { Lake } \\
\text { III }\end{array}$ & $\begin{array}{l}\text { Lake } \\
\text { IV }\end{array}$ & $\begin{array}{c}\text { Lake } \\
\text { V }\end{array}$ & Frequency & $\begin{array}{c}\text { Different pairs } \\
\text { possible among the } \\
\text { plant sp. }\end{array}$ \\
\hline 1 & Aeschynomene aspera & + & + & + & - & - & 3 & $\mathrm{~K}+\mathrm{L}, \mathrm{L}+\mathrm{F}, \mathrm{K}+\mathrm{F}$ \\
\hline 2 & Alternanthera pubescence & + & + & + & - & + & 4 & $\mathrm{~K}+\mathrm{L}, \mathrm{L}+\mathrm{F}, \mathrm{F}+\mathrm{Z}, \mathrm{K}+\mathrm{Z}$ \\
\hline 3 & Alternanthera sessilis & + & + & + & + & + & 5 & $\begin{array}{c}\mathrm{K}+\mathrm{L}, \mathrm{L}+\mathrm{F}, \mathrm{F}+\mathrm{P}, \mathrm{P}+\mathrm{Z}, \\
\mathrm{K}+\mathrm{Z}\end{array}$ \\
\hline 4 & Ammania bacifera & + & + & - & + & - & 3 & $\mathrm{~K}+\mathrm{L}, \mathrm{L}+\mathrm{P}, \mathrm{K}+\mathrm{P}$ \\
\hline 5 & Aponogeton natans & - & - & + & - & - & 1 & $\mathrm{~F}$ \\
\hline 6 & Blyxa aubertii & - & + & - & - & - & 1 & $\mathrm{~L}$ \\
\hline 7 & Butomopsis lanceolata & - & + & - & - & - & 1 & $\mathrm{~L}$ \\
\hline 8 & Chara deliculata & - & + & + & - & + & 3 & $\mathrm{~L}+\mathrm{F}, \mathrm{F}+\mathrm{Z}, \mathrm{L}+\mathrm{Z}$ \\
\hline 9 & Commelina benghalensis & - & - & + & - & - & 1 & $\mathrm{~F}$ \\
\hline 10 & Eclipta prostrata & + & + & + & + & - & 4 & $\mathrm{~K}+\mathrm{L}, \mathrm{L}+\mathrm{F}, \mathrm{F}+\mathrm{P}, \mathrm{K}+\mathrm{P}$ \\
\hline 11 & Elytrophorus spicatus & - & - & - & + & - & 1 & $\mathrm{P}$ \\
\hline 12 & Evolvulus nummularius & + & + & + & + & + & 5 & $\begin{array}{c}\mathrm{K}+\mathrm{L}, \mathrm{L}+\mathrm{F}, \mathrm{F}+\mathrm{P}, \mathrm{P}+\mathrm{Z}, \\
\mathrm{K}+\mathrm{Z}\end{array}$ \\
\hline 13 & Gnaphalium polycaulon & + & + & - & + & + & 4 & $\mathrm{~K}+\mathrm{L}, \mathrm{L}+\mathrm{P}, \mathrm{P}+\mathrm{Z}, \mathrm{K}+\mathrm{Z}$ \\
\hline 14 & Grangea maderaspatana & + & + & + & + & + & 5 & $\begin{array}{c}\mathrm{K}+\mathrm{L}, \mathrm{L}+\mathrm{F}, \mathrm{F}+\mathrm{P}, \mathrm{P}+\mathrm{Z}, \\
\mathrm{K}+\mathrm{Z}\end{array}$ \\
\hline 15 & Heliotropium indicum & + & + & $=$ & + & - & 3 & $\mathrm{~K}+\mathrm{L}, \mathrm{L}+\mathrm{P}, \mathrm{K}+\mathrm{P}$ \\
\hline 16 & Hydrila verticillata & - & + & - & - & + & 2 & $\mathrm{~L}+\mathrm{Z}$ \\
\hline 17 & Hygrophila auriculata & + & + & + & + & + & 5 & $\begin{array}{c}\mathrm{K}+\mathrm{L}, \mathrm{L}+\mathrm{F}, \mathrm{F}+\mathrm{P}, \mathrm{P}+\mathrm{Z}, \\
\mathrm{K}+\mathrm{Z}\end{array}$ \\
\hline 18 & Ipomoea aquatica & + & + & + & - & + & 4 & $\mathrm{~K}+\mathrm{L}, \mathrm{L}+\mathrm{F}, \mathrm{F}+\mathrm{Z}, \mathrm{K}+\mathrm{Z}$ \\
\hline 19 & Ipomoea fistula & + & + & + & + & + & 5 & $\begin{array}{c}\mathrm{K}+\mathrm{L}, \mathrm{L}+\mathrm{F}, \mathrm{F}+\mathrm{P}, \mathrm{P}+\mathrm{Z}, \\
\mathrm{K}+\mathrm{Z}\end{array}$ \\
\hline 20 & Limnophila heterophylla & - & + & - & - & - & 1 & $\mathrm{~L}$ \\
\hline 21 & Ludvigia ascendence & - & + & + & - & - & 2 & $\mathrm{~L}+\mathrm{F}$ \\
\hline 22 & Ludvigia parviflora & + & + & + & + & + & 5 & $\begin{array}{c}\mathrm{K}+\mathrm{L}, \mathrm{L}+\mathrm{F}, \mathrm{F}+\mathrm{P}, \mathrm{P}+\mathrm{Z}, \\
\mathrm{K}+\mathrm{Z}\end{array}$ \\
\hline 23 & Marsilea quadrifolia & + & + & + & - & + & 4 & $\mathrm{~K}+\mathrm{L}, \mathrm{L}+\mathrm{F}, \mathrm{F}+\mathrm{Z}, \mathrm{K}+\mathrm{Z}$ \\
\hline 24 & Najas graminea & - & - & + & - & - & 1 & $\mathrm{~F}$ \\
\hline 25 & Nitella gracillis & + & + & + & + & + & 5 & $\begin{array}{c}\mathrm{K}+\mathrm{L}, \mathrm{L}+\mathrm{F}, \mathrm{F}+\mathrm{P}, \mathrm{P}+\mathrm{Z}, \\
\mathrm{K}+\mathrm{Z}\end{array}$ \\
\hline 26 & Nymphaea nauchali & + & + & + & - & - & 3 & $\mathrm{~K}+\mathrm{L}, \mathrm{L}+\mathrm{F}, \mathrm{K}+\mathrm{F}$ \\
\hline 27 & Nymphea sp. & - & - & + & - & + & 2 & $\mathrm{~F}+\mathrm{Z}$ \\
\hline 28 & Nymphoides hydrophylla & + & + & + & - & + & 4 & $\mathrm{~K}+\mathrm{L}, \mathrm{L}+\mathrm{F}, \mathrm{F}+\mathrm{Z}, \mathrm{K}+\mathrm{Z}$ \\
\hline 29 & Nymphoides indicum & - & + & - & - & - & 1 & $\mathrm{~L}$ \\
\hline 30 & Oryza sp. & - & + & + & - & - & 2 & $\mathrm{~L}+\mathrm{F}$ \\
\hline 31 & Otelia alismoidis & - & + & + & - & - & 2 & $\mathrm{~L}+\mathrm{F}$ \\
\hline 32 & Phyla nodiflora & + & - & + & + & + & 4 & $\mathrm{~K}+\mathrm{F}, \mathrm{F}+\mathrm{P}, \mathrm{P}+\mathrm{Z}, \mathrm{K}+\mathrm{Z}$ \\
\hline 33 & Pistia strtiotes & - & - & + & - & - & 1 & $\mathrm{~F}$ \\
\hline 34 & Polygonum glybrum & - & + & - & - & - & 1 & $\mathrm{~L}$ \\
\hline 35 & Potamogeton crispus & - & + & - & - & - & 1 & $\mathrm{~L}$ \\
\hline 36 & Potamogeton natans & - & + & + & - & - & 2 & $\mathrm{~L}+\mathrm{F}$ \\
\hline 37 & Potamogeton sp. & + & + & - & - & - & 2 & $\mathrm{~K}+\mathrm{L}$ \\
\hline 38 & Rotala fimbriata & - & - & - & + & + & 2 & $\mathrm{P}+\mathrm{Z}$ \\
\hline 39 & Sacciolepsis intrupta & + & + & - & - & - & 2 & $\mathrm{~K}+\mathrm{L}$ \\
\hline 40 & Schenoplectus sp. & + & + & - & - & + & 3 & $\mathrm{~K}+\mathrm{L}, \mathrm{L}+\mathrm{Z}, \mathrm{K}+\mathrm{Z}$ \\
\hline 41 & Striga densifera & - & + & - & - & - & 1 & $\mathrm{~L}$ \\
\hline 42 & Typha angustifolia & - & - & + & + & + & 3 & $\mathrm{~F}+\mathrm{P}, \mathrm{P}+\mathrm{Z}, \mathrm{F}+\mathrm{Z}$ \\
\hline 43 & Utricularia reticulata & + & + & + & - & - & 3 & $\mathrm{~K}+\mathrm{L}, \mathrm{L}+\mathrm{F}, \mathrm{K}+\mathrm{F}$ \\
\hline 44 & Vallisneria spiralis & - & + & + & - & + & 3 & $\mathrm{~L}+\mathrm{F}, \mathrm{F}+\mathrm{Z}, \mathrm{L}+\mathrm{Z}$ \\
\hline
\end{tabular}




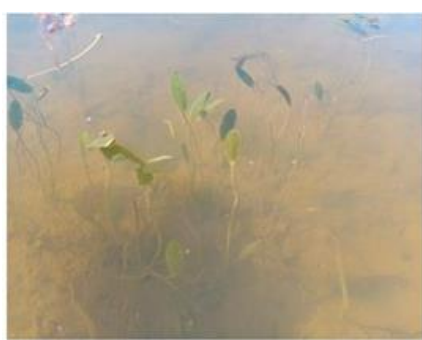

Potamogeton natans

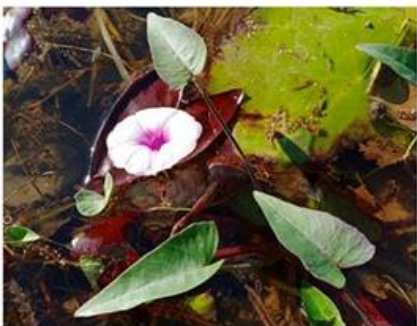

Ipomoea aquatica

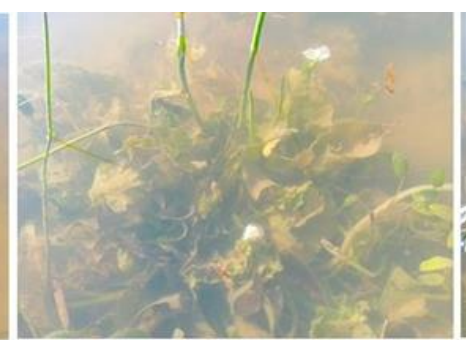

Ottelia alismoidis

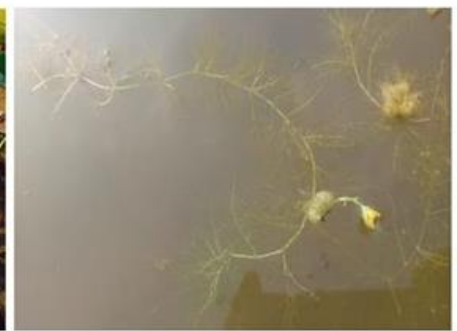

Utricularia reticulata

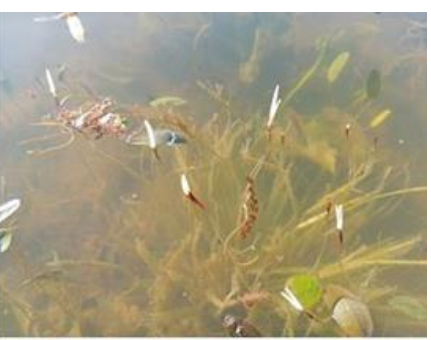

Blyxa aubertii

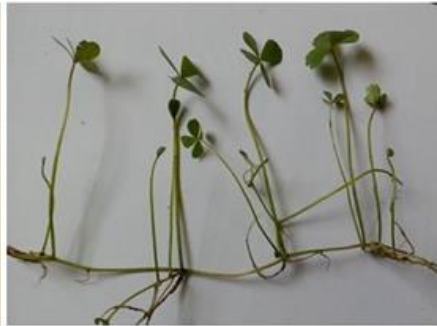

Marsilea quadrifolia
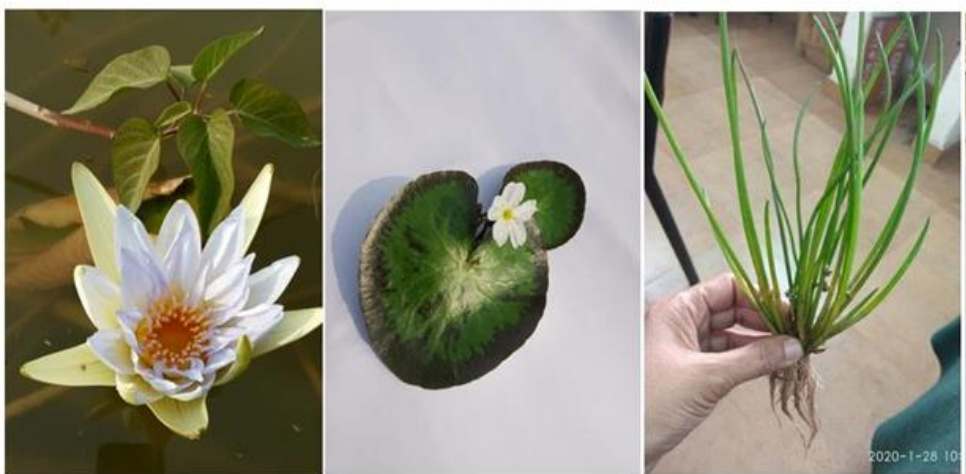

Nymphaea nauchali

Nymphoides hydrophylla

Schenoplectus sp.

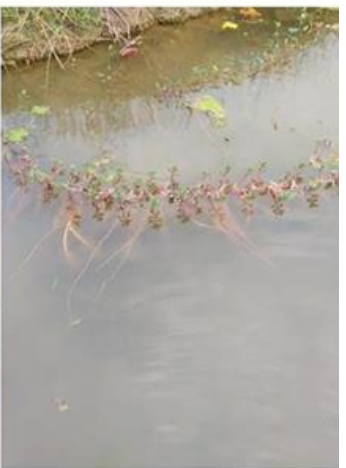

Ludvigia ascendence

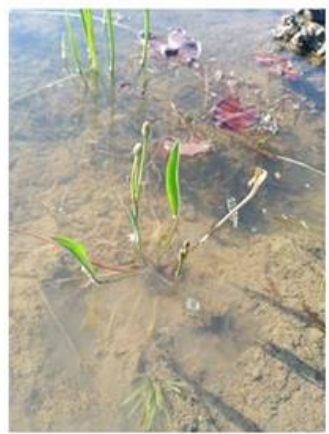

Butomopsis lanceolata

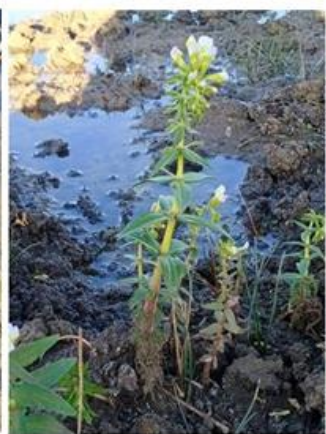

Limnophila heterophylla

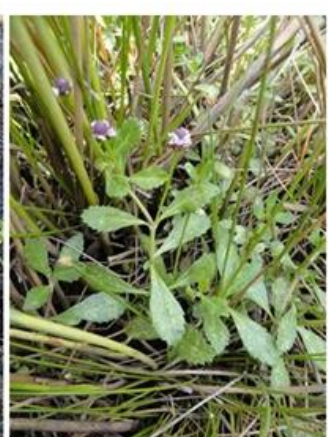

Phyla nodiflora

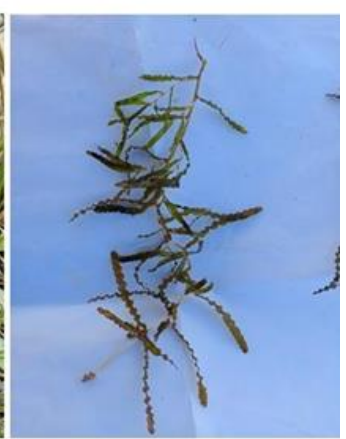

Potamogeton crispus

Figure 5. Some plants recorded from selected 5 sites

The inconsistent water depth of the lakes leads to the growth of various species in a specified micro habitat. The collected aquatic plants of these lakes can be classified into different micro-habit groups [43]. Among the total collected plants, 21 (48\%) species belong to the emergent type followed by $11(25 \%)$ species of the rooted floating type, $8(18 \%)$ species of the rooted-submerged, and 4 (9\%) species of the free floating type. If observed based on the distribution by lakes, the emergent plants were equally distributed in all lakes, however, the rooted floating and free floating plants were found in negligible numbers in Lake IV and V which are deeper than the other lakes. Submerged plants were also observed in similar numbers in all the lakes (Table 1, Figure 6).

As per the Jaccard's similarity index, Lake I and II have maximum similarity $(0.58 \%)$ and highest diversity as compared to other sites. 
The sites Lake I and V, Lake II and III, Lake III and $\mathrm{V}$ showed equal similarity $(0.50 \%)$, but they are less diverse than Lake I and II. The lowest similarity index was observed in Lake II and IV (0.28 \%) and Lake III and IV $(0.30 \%)$, indicating lesser diversity. Sorenson's similarity index has also given the same observation that Lake I and Lake II have more similarity $(0.73 \%)$ and higher diversity, while Lake II and Lake IV indicated low similarity $(0.44 \%)$ and less diversity. As per Sorenson's coefficient, lake combinations like I and III, I and IV, II and III, II and V, III and $\mathrm{V}$, IV and V showed similarity index in the range between 0.60 to $0.66 \%$ (Tables 5, 6 and 7).

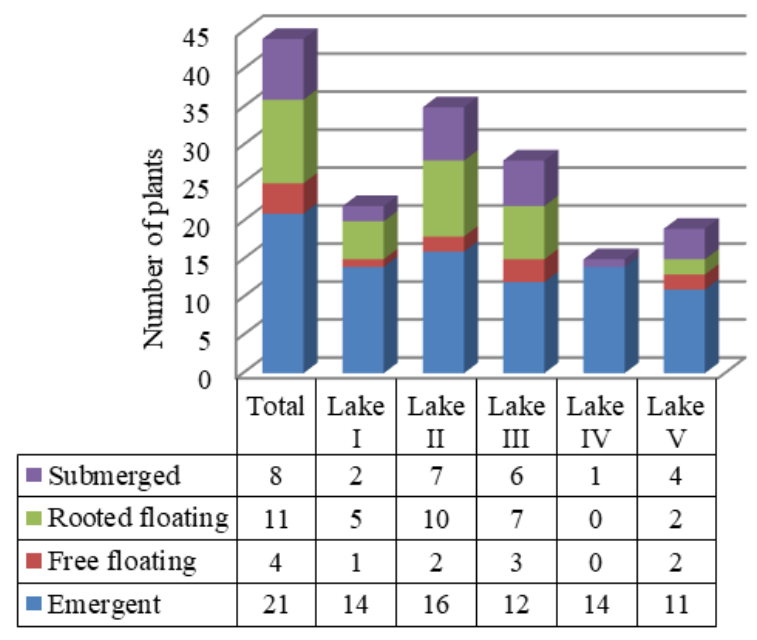

Figure 6. Lakewise distribution of plant types

Table 5. Location wise distribution of aquatic plants

\begin{tabular}{|c|c|c|c|c|c|}
\hline $\begin{array}{c}\text { Lake } \\
\text { I }\end{array}$ & & & & & \\
\hline $\begin{array}{c}\text { Lake } \\
\text { II }\end{array}$ & $\begin{array}{c}11111111111 \\
111111111111 \\
\end{array}$ & & & & \\
\hline $\begin{array}{l}\text { Lake } \\
\text { III }\end{array}$ & 1111 & $\begin{array}{c}11111111111 \\
1111111111 \\
1\end{array}$ & & & \\
\hline $\begin{array}{c}\text { Lake } \\
\text { IV }\end{array}$ & 111 & 111 & 1111111111 & & \\
\hline \multirow[t]{2}{*}{$\begin{array}{c}\text { Lake } \\
\mathrm{V}\end{array}$} & $\begin{array}{c}11111111111 \\
1111\end{array}$ & 111 & 11111111 & $\begin{array}{c}11111 \\
111111 \\
\end{array}$ & \\
\hline & $\begin{array}{c}1111111111 \\
11111111111 \\
11111111111 \\
1111111111111 \\
\end{array}$ & $\begin{array}{c}11111111111 \\
11111111111 \\
11111111111 \\
11111 \\
\end{array}$ & $\begin{array}{c}11111111111 \\
1111111111 \\
11\end{array}$ & $\begin{array}{c}11111 \\
1111111\end{array}$ & \\
\hline Lakes & Lake I & Lake II & $\begin{array}{c}\text { Lake } \\
\text { III }\end{array}$ & $\begin{array}{c}\text { Lake } \\
\text { IV }\end{array}$ & $\begin{array}{c}\text { Lake } \\
\mathrm{V}\end{array}$ \\
\hline
\end{tabular}

Table 6. Use of Jaccard's coefficient to find similarity, \%

\begin{tabular}{|c|c|c|c|c|c|}
\hline I & & & & & \\
\hline II & $\begin{array}{c}21 / 21+14+1 \\
=0.58\end{array}$ & & & & \\
\hline III & $\begin{array}{c}16 / 16+12+6 \\
=0.47\end{array}$ & $\begin{array}{c}21 / 21+7+14 \\
=0.50\end{array}$ & & & \\
\hline IV & $\begin{array}{c}12 / 12+3+10 \\
=0.48\end{array}$ & $\begin{array}{c}11 / 11+4+24 \\
=0.28\end{array}$ & $\begin{array}{c}10 / 10+5+18 \\
=0.30\end{array}$ & & \\
\hline V & $\begin{array}{c}14 / 14+6+8 \\
=0.50\end{array}$ & $\begin{array}{c}16 / 16+4+17 \\
=0.43\end{array}$ & $\begin{array}{c}16 / 16+4+12 \\
=0.50\end{array}$ & $\begin{array}{c}11 / 11+9+4 \\
=0.45\end{array}$ & \\
\hline Lakes & $\begin{array}{c}\text { Lake } \\
\text { I }\end{array}$ & $\begin{array}{c}\text { Lake } \\
\text { II }\end{array}$ & $\begin{array}{c}\text { Lake } \\
\text { III }\end{array}$ & $\begin{array}{c}\text { Lake } \\
\text { IV }\end{array}$ & $\begin{array}{c}\text { Lake } \\
\text { V }\end{array}$ \\
\hline
\end{tabular}

Table 7. Use of Sorenson's coefficient to find similarity, $\%$

\begin{tabular}{|c|c|c|c|c|c|}
\hline I & & & & & \\
\hline II & $\begin{array}{c}2(21) / 2(21) \\
+14+1= \\
0.73\end{array}$ & & & & \\
\hline III & $\begin{array}{c}2(16) / 2(16) \\
+12+6= \\
0.64\end{array}$ & $\begin{array}{c}2(21) / 2(21) \\
+7+14= \\
0.66\end{array}$ & & & \\
\hline IV & $\begin{array}{c}2(12) / 2(12) \\
+3+10= \\
0.64\end{array}$ & $\begin{array}{c}2(11) / 2(11) \\
+4+24= \\
0.44\end{array}$ & $\begin{array}{c}2(10) / 2(10) \\
+5+18= \\
0.46\end{array}$ & & \\
\hline $\mathrm{V}$ & $\begin{array}{c}2(14) / 2(14) \\
+6+8= \\
0.66\end{array}$ & $\begin{array}{c}2(16) / 2(16) \\
+4+17= \\
0.60\end{array}$ & $\begin{array}{c}2(16) / 2(16) \\
+4+12= \\
0.66\end{array}$ & $\begin{array}{c}2(11) / 2(11) \\
+9+4= \\
0.62\end{array}$ & \\
\hline Lakes & $\begin{array}{c}\text { Lake } \\
\text { I }\end{array}$ & $\begin{array}{c}\text { Lake } \\
\text { II }\end{array}$ & $\begin{array}{l}\text { Lake } \\
\text { III }\end{array}$ & $\begin{array}{l}\text { Lake } \\
\text { IV }\end{array}$ & $\begin{array}{c}\text { Lake } \\
\mathrm{V}\end{array}$ \\
\hline
\end{tabular}

\section{CONCLUSION}

The present work revealed the database of aquatic plants in water bodies around Gondia city which will act as authentic baseline documentation useful for further exploration and conservational studies of the local biodiversity. The vegetation of selected lakes is very interesting and diverse. The total of 44 species of aquatic plants representing 37 genera belonging to 26 families have been recorded. The present research work focuses on the floristic diversity and phytosociological association of the selected lakes. These lakes are good habitats, as there is no excessive growth of any invasive species. The present study also emphasized the influence of morphometric factors, like depth, on aquatic plant diversity. This kind of information is definitely essential for the establishment of truly sustainable management plan for these lakes. It is concluded that the floristic survey and constant monitoring of aquatic and semiaquatic bodies are the need of the hour in order 
to save the aquatic flora and to maintain the wild progenitors of the wetland plants.

\section{REFERENCES}

[1] D.N. Aher, V.D. Kele, K.D. Malwade, M.D. Shelke, Lake Water Quality Indexing to Identify Suitable Sites For Household Utility: A Case Study Jambhulwadi Lake; Pune (MS), International Journal of Engineering Research and Applications 6(2016) 5, 16-21.

[2] N. Bassi, M.K. Dinesh, A. Sharma, P. Pardha-Saradhi, Status of wetlands in India: A review of extent, ecosystem benefits, threats \& management strategies, Journal of Hydrology: Regional Studies 2(2014), 1-19.

[3] R. Xia, Y. Zhang, A. Critto, J. Wu, J. Fan, Z. Zheng, Y. Zhang, The Potential Impacts of Climate Change Factors on Freshwater Eutrophication: Implications for Research and Countermeasures of Water Management in China, Sustainability 8(2016) 3, 229.

[4] B. Tasleem, Study of hydrophytes of Narsarha Talab of Shahdol District Madhya Pradesh India, International Journal of Biology Research 1(2016) 3, 30-32.

[5] S. Subhadrshini, S.K. Nayak, K.B. Satapathy, Study of Floral diversity with special reference to Hydrophytes in Bhubaneswar and its adjoining areas, Odisha, India, International Research Journal of Biological Sciences 5(2016) 9, 1-7.

[6] R. Lakshmanan, S.A. Gathi, Hydrophytes of Selected wetlands of Tirunelveli district TamilNadu, India, International Journal of Fisheries and Aquatic Research 3(2018) 4, 45-49.

[7] A.A. Agostinho, F.M. Pelicice, A.C. Petry, L.C. Gomes, H.F. Júlio Jr., Fish diversity in the upper Parana River Basin: Habitats, fisheries, management and conservation, Aquatic Ecosystem Health and Management 10(2007) 2, 174-186.
[8] H.J. Theel, E.D. Dibble, An experimental simulation of an exotic aquatic macrophyte invasive and its influence on foraging behavior of bluegill, Journal of Freshwater Ecology 23(2008) 1, 79-89.

[9] S.M. Thomaz, F.A. Esteves, K.J. Murphy, A.M. dos Santos, A. Caliman, R.D. Guariento, Aquatic macrophytes in the tropics: ecology of populations and communities impacts of invasions and use by man, Tropical Biology and conservation Management, Vol. IV, 2008.

[10] K. Shutoh, T. Yamanouchi, S. Kato, H. Yamagishi, Y. Ueno, S. Hiramatsu, J. Nishihiro, T. Shiga, The aquatic macrophyte flora of a small pond revealing high species richness in the Aomori Prefecture, Japan, Journal of Asia-Pacific Biodiversity 12(2019), 448458.

[11] U. Deka, S.K. Sarma, Present status of aquatic macrophytes of the wetlands of Nalbari district of Assam, India, Asian Journal of Plant Science and Research 4(2014) 3, 67-75.

[12] S. Kumar, E.P. Chelak, Survey of Macrophytic Diversity in different ponds of Dongargarh city of Chhattisgarh, Journal of Environmental Science, Toxicology \& Food Technology 1(2015) 1, 57-59.

[13] P. Sharma, H.S. Dwivedi, Diversity of Aquatic Macrophytes of Govardhan Sagar water body at Ujjain (MP) India, International Journal Advance Research in Biological Sciences 3(2016) 8, 89-93.

[14] H. Saini, N. Kumar, Assessment and Identification of Aquatic Diversity of Wetlands of Yamuna Nagar District, Haryana, India, International Journal Life Sciences Scientific Research 3(2017) 4, 1253-1261.

[15] N.M. Dongarwar, U. Thakur, A. Fulzele, N. Labhane, Diversity of wetland plants from Umrer Tahsil of Nagpur District A preliminary study, Journal of Science Information sp. issue 3(2012), 132-135.

[16] B.K. Dalasingh, S. Parida, D. Bhattacharyay, G. Mahalik, Diversified Hydrophytes in Different Aquatic 
Habitats of Puri District, Odisha, India, Advances in Zoology and Botany 7(2019) 3, 53-60.

[17] Y. Chen, J. Chen, T. Lei, A comparative study on endangered seed plant species between China and Japan, Biodiversity Science 16(2008) 3, 255.

[18] Anonymous, Report of Irrigation department on waterbodies of Gondia district submitted to Government of Maharashtra, 2018.

[19] https://www.google.co.in/maps/@ 21.4 $835538,80.2085976,966 \mathrm{~m} /$ data $=! 3 \mathrm{~m} 1 ! 1 \mathrm{e}$ 3?hl=en \& authuser=0, Accessed: March $11,2020$.

[20] https://www.google.co.in/maps/@ 21.5 $219616,80.1447732,1671 \mathrm{~m} /$ data $=! 3 \mathrm{~m} 1 ! 1$ e3?hl=en\& authuser $=0$, Accessed: March 11, 2020.

[21] https://www.google.co.in/maps/@ 21.4 $356449,80.2025418,591 \mathrm{~m} /$ data $=! 3 \mathrm{~m} 1 ! 1 \mathrm{e}$ 3?hl=en\& authuser=0, Accessed: March $11,2020$.

[22] https://www.google.co.in/maps/@ 21.4 $116433,80.1054907,2365 \mathrm{~m} /$ data $=! 3 \mathrm{~m} 1 ! 1$ e3?hl=en\& authuser $=0$, Accessed: March 11, 2020.

[23] https://www.google.co.in/maps/@ 21.4 $298106,80.1951826,703 \mathrm{~m} /$ data $=! 3 \mathrm{~m} 1 ! 1 \mathrm{e}$ 3?hl=en\& authuser $=0$, Accessed: March $11,2020$.

[24] N.P. Singh, S. Karthikeyan, Flora of Maharashtra state: Dicotyledons, Vol. I, Botanical Survey of India, Howrah, Calcutta, India, 2000.

[25] N.R. Ugemuge, Flora of Nagpur district, Shree Publication, Nagpur, India, 1986.

[26] S.R. Yadav, M.M. Sardesai, Flora of Kolhapur district, Shivaji University Kolhapur, India, 2002.

[27] N.P. Singh, K.K. Khanna, V. Mudgal, R.D. Dixit, Flora of Madhya Pradesh Botanical Survey of India, Howrah, Calcutta, India, 2001.

[28] P. Jaccard, The distribution of flora in the alpine zone, New Phytologist 11(1912) 2, 37-50.

[29] T. Sorensen, A method of establishing groups of equal amplitude in plant sociology based on similarity of species content, Kongelige Danske
Videnskabernes Selskabs Biologiske Skrifter 5(1948), 1-34.

[30] C.M. Lorenz, B.A. Markert, A.M. Breure, G.H. Zechmeister, Bioindicators for ecosystem management with special reference to freshwater system, in: B.A. Markert, A.M. Breure, G.H. Zechmeister (eds), Bio-indicators \& Bio monitors: principles concepts \& applications, Elsevier, Amsterdam, 2003, 123-152.

[31] S. Boyra, L.N. Patralekh, Diversity of Hydrophytes of Sen Pokhar of Nonihat, Dumka, The Biobrio: An International Quarterly Journal of Life Sciences 3(2016) 3\&4, 201-204.

[32] M.M. Azzella, R. Bolpagni, A. Oggioni, Preliminary evaluation of lake morphometric traits influence on the maximum colonization depth of aquatic plants, Journal of Limnology 73(2014) 2, 400-406

[33] K.M. Wantzen, K.O. Rothhaupt, M. Mortl, Ecological effects of water-level fluctuations in lakes: an urgent issue, Hydrobiologia 613(2008), 1-4.

[34] J.A. Strand, S.E.B. Weisner, Morphological plastic responses to water depth and wave exposure in an aquatic plant (Myriophyllum spicatum), Journal of Ecology 89(2001), 166-175.

[35] G.R. Zhu, W. Li, M. Zhang, Adaptation of submerged macrophytes to both water depth and flood intensity as revealed by their mechanical resistance, Hydrobiologia 696(2012), 77-93.

[36] T. Bucak, E.C.E. SaraoĞLu, E.E. Levİ, The influence of water level on macrophyte growth and trophic interactions in eutrophic mediterranean shallow lakes: a mesocosm experiment with and without fish, Freshwater Biology 57(2012), 1631-1642.

[37] H. Fu, G.X. Yuan, T. Cao, An alternative mechanism for shade adaptation: implication of allometric responses of three submersed macrophytes to water depth, Ecological Research 27(2012), 1087-1094.

[38] G.R. Zhu, W. Li, M. Zhang, Adaptation of submerged macrophytes to both water depth and flood intensity as revealed by 
their mechanical resistance, Hydrobiologia 696(2012), 77-93.

[39] B.L. Dong, B.Q. Qin, G. Gao, Submerged macrophyte communities and the controlling factors in large, shallow lake Taihu (China): sediment distribution and water depth, Journal of Great Lakes Research 40(2014), 646655.

[40] W.P. Sousa, The role of disturbance in natural communities, Annual Reviews of Ecology and Systematics 15(1984), 353391.

[41] M.M. Pollock, R.J. Naiman, T.A. Hanley, Plant species richness in riparian wetlands - a test of biodiversity theory, Ecology 79(1998), 94-105.

[42] D. Zervas, I. Tsiripidis, E. Bergmeier, V. Tsiaoussi, A phytosociological survey of aquatic vegetation in the main freshwater lakes of Greece, Vegetation Classification \& Survey 1(2020), 53-75.

[43] R.F. Daubenmire, Plant and Environment. John Willey and Sons, New York, 1947. 